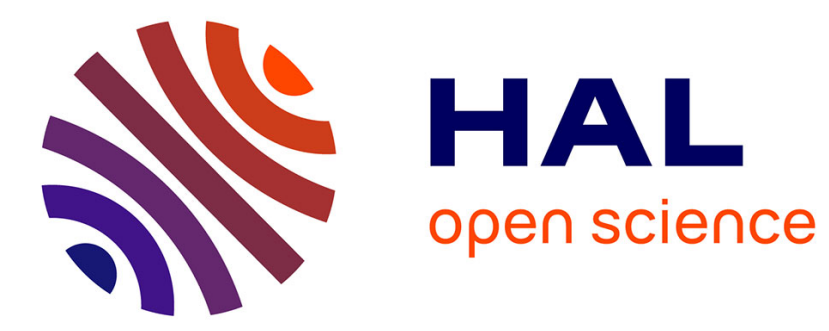

\title{
R.F. sputtered amorphous silicon schottky Barrier solar cells
}

\author{
M. J. Thompson, J. Allison, M. M. Al-Kaisi, I.P. Thomas
}

\section{To cite this version:}

M. J. Thompson, J. Allison, M. M. Al-Kaisi, I.P. Thomas. R.F. sputtered amorphous silicon schottky Barrier solar cells. Revue de Physique Appliquée, 1978, 13 (12), pp.625-628. 10.1051/rphysap:019780013012062500 . jpa-00244514

\section{HAL Id: jpa-00244514 https://hal.science/jpa-00244514}

Submitted on 1 Jan 1978

HAL is a multi-disciplinary open access archive for the deposit and dissemination of scientific research documents, whether they are published or not. The documents may come from teaching and research institutions in France or abroad, or from public or private research centers.
L'archive ouverte pluridisciplinaire HAL, est destinée au dépôt et à la diffusion de documents scientifiques de niveau recherche, publiés ou non, émanant des établissements d'enseignement et de recherche français ou étrangers, des laboratoires publics ou privés. 


\title{
PHOTODETECTORS.
}

\section{R.F. SPUTTERED AMORPHOUS SILICON SCHOTTKY BARRIER SOLAR CELLS}

\author{
M. J. THOMPSON, J. ALLISON, M. M. AL-KAISI and I. P. THOMAS \\ Department of Electronic Engineering, University of Sheffield, U.K.
}

\begin{abstract}
Résumé. - On a discuté de la préparation des films a-Si hydrogéné, obtenus par pulvérisation r.f. et pouvant conduire à des cellules solaires de grandes dimensions. On a détaillé la mesure optique et électrique sur de pareils matériaux en rapport avec une diversité de métaux. On a décrit des éléments prototypes et expérimentaux ayant des dimensions jusqu'à $1 \mathrm{~cm}^{2}$ et des efficacités de $2 \%$ environ.

Abstract. - The preparation of hydrogenated, r.f. sputtered a-Si films, suitable for large area solar cell arrays is discussed. Optical and electrical measurements on such materials contacted with a variety of metals are detailed. Initial experimental prototype cells, with areas up to $1 \mathrm{~cm}^{2}$ and efficiencies of around $2 \%$, are described.
\end{abstract}

1. Introduction. - We have been studying an alternative technology to glow discharge decomposition of silane $[1,2]$ for the production of thin film a-Si solar cells, using r.f. sputtering methods. The process has considerable industrial potential because of the large area, continuous processing capability and consequent low device cost. We have found that good quality a-Si can be produced by r.f. sputtering in a hydrogen-argon atmosphere. The hydrogen causes a reduction in the defect density and consequently a nine orders of magnitude change in the resistivity of the deposited film [3]. The quantum efficiency of photoluminescence, which has been shown to be a good measure of the density of states in the pseudogap [4], is similar in our material to that for glow discharge material produced by the Dundee group [5].

The production of r.f. sputtered a-Si with optimum electrical and optical properties for efficient solar cell fabrication and the influence of the metal contacts on device performance have been studied. $\mathrm{Si}$ is sputtered from a vacuum melted pure Si target in an argon-hydrogen atmosphere. An overall area of a-Si of $100 \mathrm{~cm}^{2}$ is deposited, allowing a large number of measurements to be made on the same material. The properties of the film do not vary appreciably over the deposited area, which illustrates the technical feasibility of large area production.

The optical absorption edge and the position and amplitude of the photoconductivity spectral response are markedly influenced by the hydrogen pressure and the substrate temperature during sputtering.

The dark and illuminated current-voltage characteristics have been measured for films prepared under various conditions and contacted with a variety of metals, such as $\mathrm{Ni}, \mathrm{Pt}, \mathrm{Pd}, \mathrm{Al}$ and $\mathrm{Au}$. Forward to back current ratios of over $1000: 1$ have been observed and series resistance effects are evident. A strong correlation between open circuit voltage and metal work function and the relation between device performance and preparation conditions is evident.
All prototype cells have so far been produced with intrinsic a-Si material, without the use of doped $\mathrm{n}^{+}$ contacts, oxidation to produced larger barrier heights and anti-reflection coatings. Despite the absence of these necessary refinements, efficiencies of over $2 \%$ have been obtained. Single cells of $1 \mathrm{~cm}^{2}$ have also been produced.

2. Device fabrication. - The samples are prepared in a sputtering chamber containing three targets and additional evaporation sources. The substrate temperature, $T_{\mathrm{s}}$, can be maintained at $20^{\circ} \mathrm{C}$ with water cooling or heated to temperatures up to $500^{\circ} \mathrm{C}$. Many parameters need to be optimised ; for example, the $\mathrm{H}_{2}$ pressure has been varied from 0 to $10^{-3}$ torr. Typical sputtering conditions are included in references [5] and [6].

3. The relationship between material properties and preparation conditions. - 3.1 ELECTRICAL PROPERTIES. - The dark conductivity of a-Si, $\sigma_{\mathrm{D}}$, and the associated activation energy $\Delta E$ have been measured as a function of $\mathrm{H}_{2}$ pressures, $p_{\mathrm{H}}$, and substrates temperature, using multilayer (sandwich) devices which consist of a thin film of a-Si provided with ohmic contacts on opposite faces.

The concept of saturating the dangling bonds by $\mathrm{H}_{2}$ atoms is reflected in the conductivity of these films as shown in figure 1 where $\sigma_{\mathrm{D}}$ and $\Delta E$ have been plotted against $p_{\mathbf{H}}$. The dark conductivity of the a-Si films decreases by eight orders of magnitude when the $\mathrm{H}_{2}$ pressure in the sputtering chamber is increased from 0 to $4 \times 10^{-4}$ torr. For higher $\mathrm{H}_{2}$ pressures the conductivity first saturates and then increases again. This perhaps indicates that newly formed localised states have been introduced by the hydrogen [7].

Increasing the substrate temperature causes a decrease in $\sigma_{\mathbf{D}}$ for samples sputtered in a pure argon atmosphere. However, for samples prepared in an 


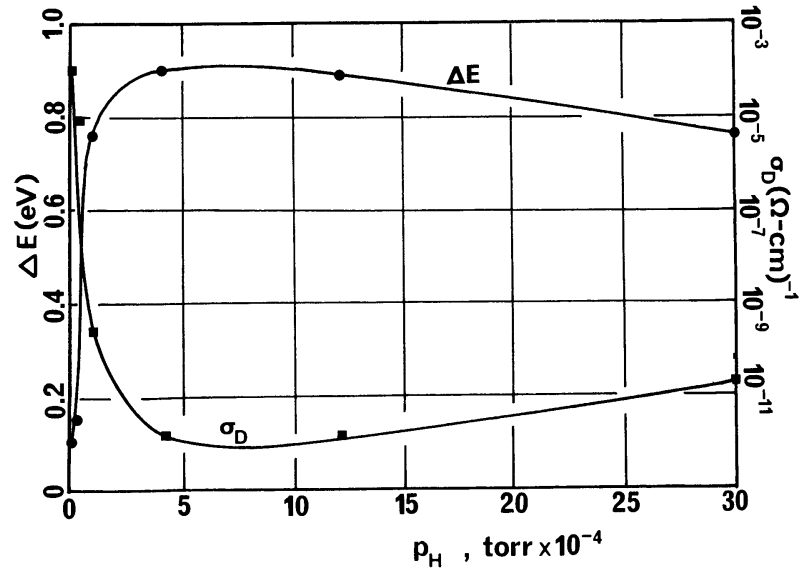

Fig. 1. - Activation energy $(\Delta E)$ and dark conductivity $\left(\sigma_{\mathrm{D}}\right)$ of a-Si versus hydrogen pressure in the sputtering gas during preparation, $p_{\mathrm{H}}$.

Ar and $\mathrm{H}_{2}$ plasma, the higher $T_{\mathrm{s}}$ the higher $\sigma_{\mathrm{D}}$. This is probably because less $\mathrm{H}_{2}$ is incorporated at temperatures higher than $250^{\circ} \mathrm{C}$, which seems the optimum temperature for the formation of the $\mathrm{Si}-\mathrm{H}$ bond [8].

For unhydrogenated a-Si, $\sigma_{\mathrm{D}}$ is activated, with $\Delta E \sim 0.1 \mathrm{eV}$, a typical activation energy found by many workers [9], which is associated with hopping transport. A singly activated $\sigma_{\mathrm{D}}$ and $\Delta E \sim 0.9 \mathrm{eV}$ is found in samples prepared with $p_{\mathbf{H}}$ higher than $1.10^{-4}$ torr; this high value of $\Delta E$ indicates that the majority of conduction is now by electrons in extended states.

The I-V characteristics for unhydrogenated $\mathrm{Si}$ $\left(p_{\mathrm{H}}=0\right) \mathrm{metal} / \mathrm{a}-\mathrm{Si} / \mathrm{metal}$ multilayer devices always obey a simple ohmic relationship with no sign of rectification even when prepared at high $T_{\mathrm{s}}$. This is due to the large number of gap states and consequently a thin depletion region.

Near ideal forward currents have been obtained with a-Si Schottky-barrier devices prepared in the presence of $4 \times 10^{-4}$ torr of $\mathrm{H}_{2}$ at $T_{5}=200^{\circ} \mathrm{C}$. Rectification ratios between $10^{3}-10^{4}$ have been obtained (see Fig. 2) with a diode quality factor, $n \sim 1.25$, indicating diffusion rather than recombination limited currents. A good fit to the equation :

$$
J=J_{0}(\exp e V / n k T-1)
$$

is obtained for these devices. However, a deviation from the exponential law occurs at high currents, when the diode series resistance $R_{\mathrm{s}}$ and metal contact $R_{\mathrm{c}}$ begin to be comparable to the effective junction resistance [10]. It appears that for samples prepared with $p_{\mathrm{H}}=4 \times 10^{-4}$ and $T_{\mathrm{s}}=200^{\circ} \mathrm{C}$, most of the localised states have been saturated, allowing the silicon to have a wide depletion region.

The typical $I-V$ characteristics for devices prepared with $p_{\mathrm{H}}=4 \times 10^{-4}$ torr, figure 2 , show that the

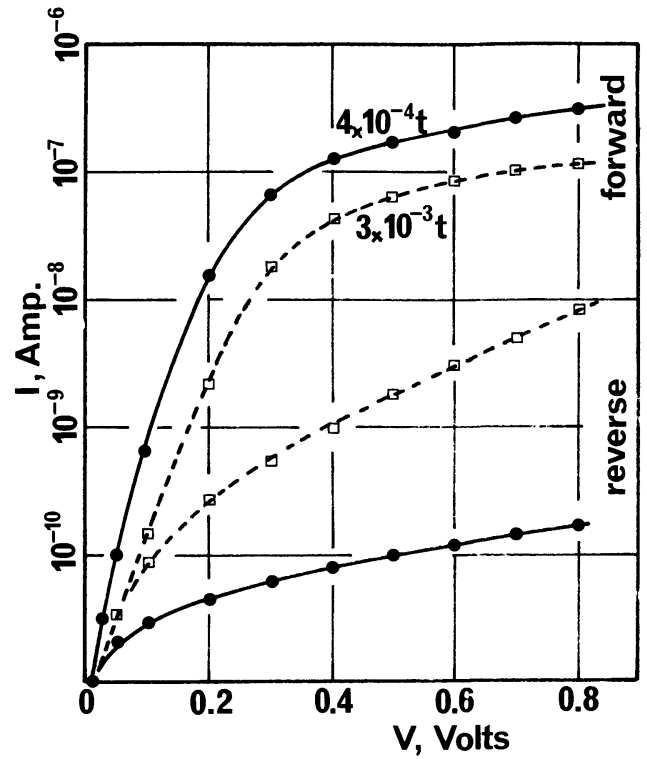

FIG. 2. - Current-voltage characteristics for two samples prepared at hydrogen pressures of $4 \times 10^{-4}$ torr and $3 \times 10^{-3}$ torr.

rectification ratio drops to around $10-20$ and in general a rise in the reverse biased current is observed when the $\mathrm{H}_{2}$ pressure exceeds this value.

3.2 Optical PROPERTIES. - It has been found that optical properties of the a-Si are also markedly influenced by $T_{\mathrm{s}}$ and $p_{\mathrm{H}}$. The absorption edge shifts to high energies as $p_{\mathrm{H}}$ is increased. For samples prepared in the same $\mathrm{H}_{2}$ atmosphere, the shift in the absorption edge is smaller for samples prepared at $T_{\mathrm{s}}=300^{\circ} \mathrm{C}$ than those sputtered at $T_{\mathrm{s}}=200^{\circ} \mathrm{C}$. The absorption curve for a sample sputtered at $p_{\mathrm{H}}=4 \times 10^{-4}$ torr and $T_{\mathrm{s}}=200^{\circ} \mathrm{C}$ corresponds roughly to that for samples produced by the glow discharge technique at $T_{\mathrm{s}}=200-300{ }^{\circ} \mathrm{C}$.

Figure 3 shows the photoconductive gain (PC) versus quantum energy for our samples. As $p_{\mathrm{H}}$ increases the $\mathrm{PC}$ response increases to a maximum at $p_{\mathrm{H}}=4 \times 10^{-4}$ torr for $T_{\mathrm{s}}=200^{\circ} \mathrm{C}$ and then falls

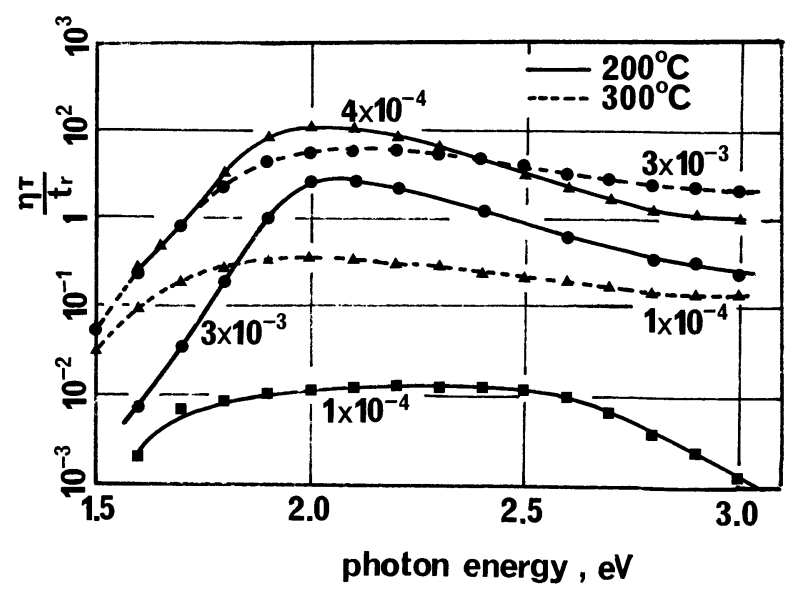

Fig. 3. - Photoconductive gain versus photon energy for films prepared at different hydrogen pressures and substrate temperatures. 
off at higher $p_{\mathrm{H}}$ values. For $T_{\mathrm{s}}=300^{\circ} \mathrm{C}$ the peak response is at higher pressures $\left(3 \times 10^{-3}\right.$ torr $)$. The results resemble those of the Harvard group [7], but in the latter work the PC response shows two maxima with increasing $p_{\mathrm{H}}$.

All the optical data is consistent with the model that the amount of $\mathrm{H}_{2}$ incorporated in the sample is reduced as $T_{\mathrm{s}}$ in increased. In addition it is interesting to note that the photoconductivity reduces at high $p_{\mathbf{H}}$ whereas the dark conductivity increases at high $p_{\mathbf{H}}$. This would be consistent with the excess hydrogen forming localised states in the a-Si.

4. Metal : a-Si Schottky barrier solar cell structures. - The previous results in section 3 provide us with the required information to choose the optimum preparation conditions for making photoconductive a-Si (i) films with few localised states in the gap, so that a wide depletion region can be formed when a rectifying metal is in contact with the amorphous layer. We have consequently chosen to prepare a-Si for devices under conditions of $p_{\mathrm{H}}=4 \times 10^{-4}$ torr and $T_{\mathrm{s}}=200^{\circ} \mathrm{C}$.

Various metals such as $\mathrm{Al}, \mathrm{Au}, \mathrm{Ni}, \mathrm{Pd}$ and $\mathrm{Pt}$ have been vacuum evaporated on the intrinsic $\mathrm{Si}$ (a-Si). The thickness of these a-Si films is of the order of $1 \mu \mathrm{m}$ and that of the rectifying metal contact is $\sim 50 \AA$. Dark $I-V$ characteristics, measured at $\mathrm{R}-\mathrm{T}$, are shown in figure 4 . These indicate a typical rectification ratio of $10^{3}$, a diode quality factor, $n$, between 1.25-1.6 and saturation current density of $\sim 10^{-12} \mathrm{~A} . \mathrm{cm}^{-2}$. It is also clear from the figure that devices with contacts with high work function such as $\mathrm{Pt}, \mathrm{Pd}, \mathrm{Au}$ have a low saturation current, whereas $\mathrm{Al}$ and $\mathrm{Ni}$

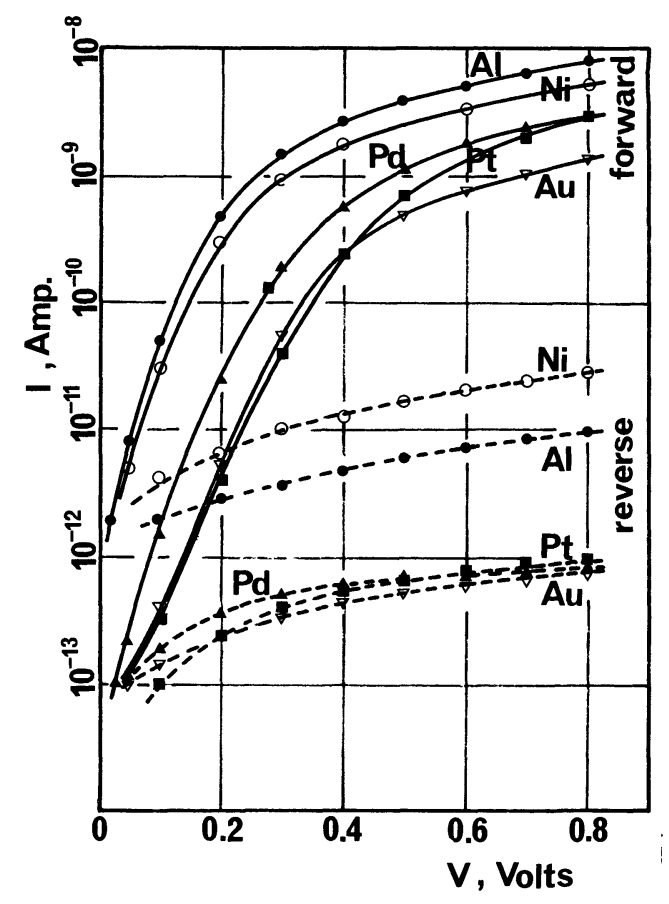

FIG. 4. - Current-voltage characteristics of a-Si Schottky barriers with different metal rectifying contacts. have a higher saturation current because of their low work function. The significance of this is reflected in the open circuit voltage values as shown in figure 5 where an approximately linear relationship between $V_{\text {oc }}$ and metal work function, $\varphi_{\mathbf{m}}$, is apparent.

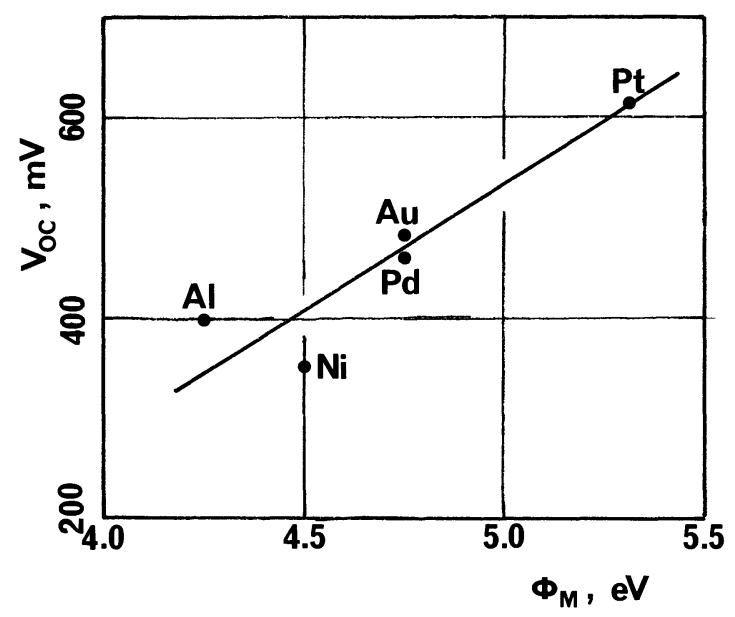

FIG. 5. - Open circuit voltage, $V_{\text {oc }}$, versus metal work function, $\varphi_{\mathrm{m}}$, for various a-Si Schottky barriers.

Devices with areas from $2 \times 10^{-3} \mathrm{~cm}^{2}$ to $1 \mathrm{~cm}^{2}$ have been tested and the results indicate that $J_{0}$ does not significantly increase with area and so reduce the open circuit voltage $V_{o c}$ of a cell, as might be anticipated from :

$$
V_{\mathrm{oc}}=\frac{n k T}{e} \ln \left\{\frac{J_{\mathrm{sc}}}{J_{0}}\right\} .
$$

Open circuit voltages as high as $600 \mathrm{mV}$ have been obtained from cells with areas as large as $\sim 1 \mathrm{~cm}^{2}$ with corresponding rectification ratios $>10^{3}$. This demonstrates the large area capability of the process and also the absence of pin holes in the films.

$\mathrm{NiCr}$ provides a good non-rectifying contact to a-Si but it creates a high series resistance which can reduce the efficiency of a cell. However, by suitable processing, a good low resistance ohmic contact can

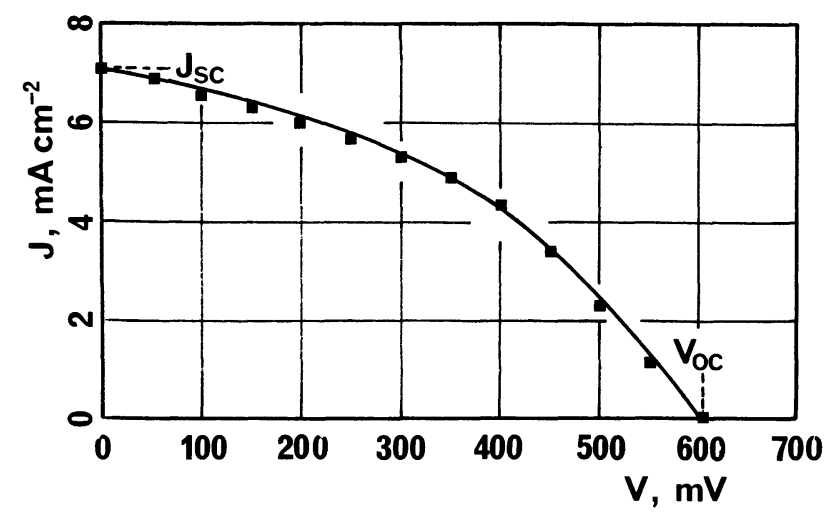

FIG. 6. - Current-voltage characteristic for a-Si : Pt device under sunlight illumination. 
be obtained with $\mathrm{Al}$. The series resistance of the a-Si films used is much smaller under illumination conditions than the dark value but it is still high compared with single crystal silicon.

A typical a-Si : Pt Schottky barrier $I-V$ characteristic under sunlight condition is shown in figure 6. Open circuit voltages of $610 \mathrm{mV}$ and short circuit current densities around $7 \mathrm{~mA} \mathrm{~cm}{ }^{-2}$ have been obtained, with a fill factor, f.f., of $\sim 0.4$. This low value of f.f. seems to be due to the effect of the high bulk resistance of the a-Si layer.

Efficiencies of $\sim 2 \%$ have been obtained from these devices $(*)$. Such rudimentary cells have no

(*) Thanks are expressed to Ferranti Ltd., Electronic Components Div., for the use of their testing facilities. anti-reflection coating or any oxide layer between the a-Si and the rectifying metal contact, which would improve the performance. Also, no $\mathrm{n}^{+}$layer has yet been used to improved the ohmic contact nor has there been any attempt to optimise contact geometry. Considerable improvement in efficiency can be anticipated when such refinements are incorporated in cell design.

5. Conclusions. - The feasibility of large area a-Si and a variety of contact materials has been demonstrated. Careful control of the preparation conditions, in particular the hydrogen pressure and the substrate temperature is necessary to produce suitable material. Initial results on experimental solar cell devices are encouraging and suggest that competitive fully engineered devices are now a possibility.

\section{References}

[1] SPEAR, W. E., LeComber, P. G., Kinmond, S. and BrodsKy, M. H., Appl. Phys. Lett. 28 (1976) 105.

[2] Carlson, D. E. and Wronski, G. A. W., Appl. Phys. Lett. 28 (1976) 671.

[3] Thompson, M. J., Allison, J., Al-Kaisi, M. M. and Barber, J., Proc. of Int. Conf. on Photovoltaic Solar Energy, Luxembourg (1977) 231.

[4] Street, R. A., Knights, J. C. and Biegelson, Phys. Rev., in press (1978).

[5] Austin, I. G., Richards, K., Searle, T. M., Thompson, M. J., Al-Kaisi, M. M., Thomas, I. P. and Allison, J., to be published in Proc. of 14th Int. Conf. on Phys. of Semiconductors (1978)

[6] Thompson, M. J., Allison, J., Al-Kaisi, M. M., Solid State Electron Devices 2 (1978).

[7] Anderson, D. A., Moustakas, T. D. and Paul, W., Proc. of 7th Int. Conf. on Amorphous and Liquid Semiconductors, Edinburgh (1977) 334.

[8] Brodsky, M. H., Thin Solid Films 50 (1978) 7.

[9] Lecomber, P. G., Madan, A. and Spear, W. E., J. NonCrystal. Sol. 99 (1972) 219.

[10] Sze, S. M., Physics of Semiconductor Devices (Wiley) 1969. 